\title{
Implementasi Metode SDLC Prototype Pada Sistem Informasi Indeks Kepuasan Masyarakat (IKM) Berbasis Website Studi Kasus Dinas Kependudukan Dan Catatan Sipil
}

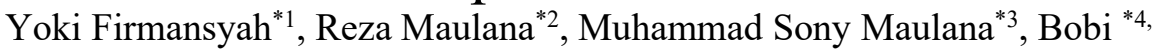

${ }^{a}$ Fakultas Teknologi Informasi, Universitas Bina Sarana Informatika Kampus Kota Pontianak Jalan Abdurraman Saleh No 18 A, Pontianak, Kalimantan Barat

\author{
${ }^{1}$ Yoki.yryebsi.ac.id \\ ${ }^{2}$ Reza.rzalbsi.ac.id \\ 3Muhammad.sony.momebsi.ac.id \\ ${ }^{4}$ Bobhi.b7@gmail.com
}

\begin{abstract}
Abstrak
Pesatnya perkembangan teknologi informasi menuntuk setiap instansi untuk menggunakan teknologi informasi dalam menjalankan aktivitas pekerjaan sehari hari, salah satunya adalah Dinas Kependudukan dan Catatan Sipil, banyak permasalahan yang terjadi dikarenakan belum memanfaatkan teknologi informasi, salah satunya yaitu pada proses survey indeks kepuasan masyarakat (IKM), permasalahannya yaitu sering terjadi kehilangan atau kerusakan data survey, dan kurang efektifnya pelaksanaan survey yang masih menggunakan kertas, belum lagi permasalahan untuk menyusun dan merekap nilai pelayanan serta kurangnya pemahaman dan timbal balik dari masyarakat. Untuk mengatasi permasalahan tersebut maka dibuatlah sebuah aplikasi sistem informasi indeks kepuasan masyarakat (IPM) berbasis website dengan memanfaatkan metode SDLC Prototype, dan untuk pengumpulan datanya digunakan metode wawancara, observasi dan wawancara, dan sistem informasi yang dibuat menggunakan bahasa PHP dan PhyMyadmin dan MySql Sebagai basis Data, dengan adanya Sistem Survey IKM yang terkomputerisasi ini diharapkan dapat menunjang kegiatan survey menjadi lebih efektif dan efisien dari sistem yang sudah ada sebelumnya

Kata kunci: Survei, Indeks Kepuasan Masyarakat, Sistem Informasi, Waterfall, Website

\section{Implementation of the SDLC Prototype Method on the Website Based Public Satisfaction Index (IKM) Information System Case Study of the Department of Population and Civil Registry}

\begin{abstract}
The rapid development of information technology requires every agency to use information technology in carrying out daily work activities, one of which is the Department of Population and Civil Registry, many problems have occurred due to not utilizing information technology, one of which is the process of surveying the community satisfaction index (IKM), the problem is that there is often loss or damage to survey data, and the ineffective implementation of surveys that are still using paper, not to mention the problems in compiling and recapitulating service values as well as a lack of understanding and feedback from the community. To solve this problem, a website-based public satisfaction index (IPM) information system application was made using the SDLC Prototype method, and for data collection, interview, observation and interview methods were used, and the information system was created using PHP and PhyMyadmin and MySql as a basis. Data, with the existence of a computerized SME Survey System, it is hoped that it can support survey activities to be more effective and efficient than the existing system.

Keywords: Survey, Community Satisfaction Index, Information System, Prototype, Website

\section{PENDAhUluan}

Semakin berkembangnya bidang teknologi informasi, menuntut setiap instansi pemerintah untuk menerapkan teknologi informasi disetiap proses pekerjaannya[1]. Alas an menggunakan system informasi dalam mendukung proses pekerjaan adalah untuk mempermudah dan mempersingkat waktu pekerjaan yang biasanya dikerjakan harus memerlukan waktu yang cukup panjang menjadi lebih mudah dan lebih ringkas [2]. Salah satu instansi

yang dapat menerapkan teknologi informasi dalam menjalankan pekerjaannya adalah dinas kependudukan dan catatan sipil.

Dinas kependudukan dan Pencatatan Sipil merupakan instansi pemerintah yang bergerak dibidang pencatatan sipil, pendataan penduduk dan pemanfaatan data yang ada pada suatu daerah disetiap kabupaten/Kota, dimana salah satu kegiatan yang dilakukan instansi tersebut adalah mengolah data data kependudukan salah satunya adalah
\end{abstract}


data Survei Indeks kepuasan masyarakat (IKM), namun berdasarkan obeservasi dan wawancara yang dilakukan ditemukan beberapa permasalahan yang terjadi dilapangan ketika proses survey IKM dilakukan, diantaranya yaitu survey masih dilakukan menggunakan media kertas dan belum menerapkan teknologi didalam proses surveinya, hal ini tentunya dapat menyebabkan berbagai permasalahan lanjutan seperti beberapa kali terhadi kehilangan data, bahkan terjadi manupulasi data yang menyebabkan data menjadi tidak akurat dan mempengarhui hasil survey kedepannya.

Maka dari itu untuk meminimalisir kesalahan diperlukan sebuah system informasi pengolahan data survey indeks kepuasan masyarakat (IKM) dalam bentuk sistem informasi berbasis website.

sistem adalah suatu uraian pekerjaan dari sebuah prosedur yang saling berinteraktif atau berpadu untuk melakukan pekerjaan dengan tujuan yang telah ditentukan sebelumnya[3], adapun system yang dibangun berbasis website dengan mengunakan bahasa PHP dan HTML. website atau yang biasa disingkat dengan web merupakan sebuah perkumpulan halaman halaman yang disediakan melalui jaringan internet dengan tujuan untuk memberikan informasi[2]. Dah PHP merupakan sebuah bahasa pemrograman yang dapat digunakan untuk membuat aplikasi berbasis web[4]. Sedangkan HTML merupakan sebuah bahasa pemrograman yang digunakan untuk membuat format teks dalam pembuatan dokumen atau data yang terdapat pada jaringan komputer[5].

Dalam pembuatan sistem informasi IKM ini juga digunakan beberapa tools pendukung seperti PhpMyadmin, Mysql, XAMPP dan Sublime text sebagai text editor, Phpmyadmin merupakan sebuah aplikasi yang berbasis website yang digunakan untuk membuat database, dan Myswl Sebagai tempat untuk menyimpan data data website tersebut[6], dan XAMPP merupakan server local yang memungkinkan pengguna untuk mengembangkan sebuah aplikasi yang berbasis website dengan apache, PHP dan database MySQL [7].

\section{METODOLOGI}

\subsection{Metode Pengembangan perangkat Lunak}

Sistem Informasi Indeks Kepuasan masyarakat (IKM) ini akan dibuat dengan mengimplementasikan model Prototype. Model prototyping merupakan suatu teknik untuk mengumpulkan informasi tertentu mengenai kebutuhan-kebutuhan informasi pengguna secara cepat Berfokus pada penyajian dari aspek-aspek perangkat lunak tersebut yang akan nampak bagi pelanggan atau pemakai. Prototipe tersebut akan dievaluasi oleh pelanggan/pemakai dan dipakai untuk menyaring kebutuhan pengembangan perangkat lunak[8]. sedangkan pendapat lain mengatakan prototyping merupakan metode pengembangan perangat lunak, yang berupa model fisik kerja sistem dan berfungsi sebagai versi awal dari sistem[9], Dengan metode prototyping ini akan dihasilkan prototype sistem sebagai perantara pengembang dan pengguna agar dapat berinteraksi dalam proses kegiatan pengembangan sistem informasi. Agar proses pembuatan prototype ini berhasil dengan baik adalah dengan mendefinisikan aturan-aturan pada tahap awal, yaitu pengembang dan penguna harus satu pemahaman bahwa prototype dibangun untuk mendefinisikan kebutuhan awal. Prototype akan dihilangkan atau ditambahkan pada bagiannya sehingga sesuai dengan perencanaan dan analisis yang dilakukan oleh pengembang sampai dengan ujicoba dilakukan secara simultan seiiring dengan proses pengembangan [10].

Model protoype ini memiliki beberapa tahapan [11], yaitu :

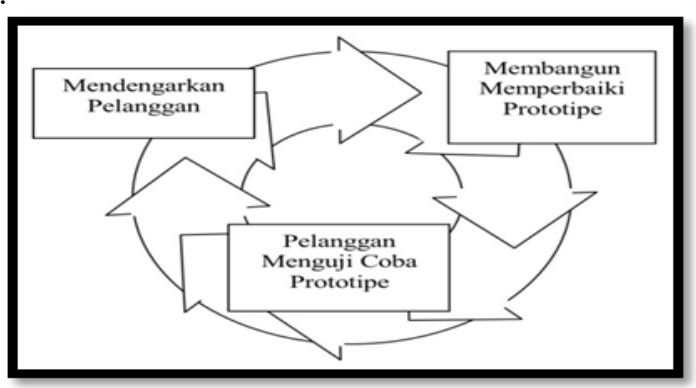

Sumber : Sukamto \& Shalahuddin, (2015) Gambar 1. Model prototype

a. Pada tahap ini dilakukan pengumpulan kebutuhan dari sistem dengan cara mendengarkan keluhan dari pelanggan. Untuk membuat suatu sistem yang sesuai kebutuhan, maka harus diketahui terlebih dahulu bagaimana sistem yang sedang berjalan untuk kemudian mengetahui masalah yang terjadi. Tahapan ini langsung dilakukan disalah satu dinas kependudukan dan pencatatan sipil yang ada di Provinsi Kalimantan barat, hal ini dilakukan untuk mengetahui permasalahan apa saja yang terjadi di perusahaan tersebut, yang nantinya akan menjadi dasar dalam pembuatan Sistem Informasi Indeks Kepuasan masyarakat (IKM)

b. Membangun dan memperbaiki prototype

Mock-up yang dimaksud merupakan sesuatu yang digunakan sebagai model desain yang digunakan untuk mengajar, demonstrasi dan evaluasi desain sistem. Mock-up akan disebut sebagai prototype apabila perangkat lunak tersebut menyediakan atau mampu mendemonstrasikan sebagian besar fungsi sistem perangkat lunak dan memungkinkan pengujian desain sistem perangkat lunak.

Pembuatan mock-up ini menggunakan bahasa pemrograman hypertext preprocessor (PHP), hypertext markup language (HTML), cascading style sheet (CSS) dan framework. Untuk memodelkan rancangan sistem ini menggunakan unified modelling language (UML) yang terdiri dari activity diagram, use case diagram, class diagram dan sequence diagram untuk memodelkan rancangan. Entity relationship diagram (ERD), logical record structure (LRS), dan spesifikasi file digunakan untuk merancang basis data.

\section{c. Pelanggan Menguji Coba Prototipe}

Setelah aplikasi dibangun, dan diperbaiki maka berikutnya adalah melakukan uji coba, dimana Sistem Informasi Indeks kepuasan masyarakat akan langsung 
diujicobakan oleh pelanggan, adapun metode pengujian yang digunakan adalah menggunakan metode blackbox testing, blackbox testing atau yang biasa disebut dengan pengujian kotak hitam dilakukan dengan membuat kasus uji yang bersifat mencoba semua fungsi dengan memakai perangkat lunak apakah sesuai dengan spesifikasi yang dibutuhkan[11] [12].

\subsection{Metode Pengumpulan Data.}

Teknik pengumpulan data merupakan teknik yang paling bagus untuk digunakan dalam suatu penelitian karena melalui penelitian kita bisa mendapatkan data-data yang kita butuhkan[13]. Untuk mendapatkan data tersebut maka digunakan teknik pengumpulan data yang meliputi:

a. Wawancara

melakukan proses tanya jawab (Wawancara) secara kepada bapak Kepala Seksi Pengolahan dan Penyajian Data Kependudukan pada Kantor Dinas Kependudukan dan Pencatatan Sipil mengenai permasalahan-permasalahan yang terdapat pada proses survei. dengan alasan ingin mengkaji lebih dalam lagi mengenai permasalahan yang ada pada proses survei tersebut. Berdasarkan hasil tanya jawab (Wawancara) tersebut maka diperoleh data-data yang terkait dengan permasalahan yang ada pada proses survei Indeks Kepuasan Masyarakat yaitu meliputi banyaknya masyarakat yang masih belum memahami maksud dan tujuan dari dilaksanakannya survei tersebut sehingga dalam pengisian data kuisioner masih banyak unsur yang tidak terisi (kosong), rentannya terjadi kehilangan data serta sulitnya dalam proses pengolahan data hasil survei.

b. Observasi

Proses Observasi dilakukan dengan cara mengamati objek penelitian secara langsung[14], yaitu langsung ke Kantor Dinas Kependudukan dan Pencatatan Sipil untuk melakukan observasi yang dilaksanakan kurang lebih selama 3 bulan Dalam kurun waktu tersebut, Dari proses obeservasi tersebut maka Ditemukan beberapa fakta yang berkaitan dengan permasalahan yang terjadi yaitu banyaknya penduduk yang belum paham tentang tujuan dan manfaat dari survei yang dilaksanakan tersebut.

c. Studi Pustaka

Studi pustaka adalah salah satu metode yang digunakan dalam pengumpulan data [15]. Yaitu dengan menganalisis buku laporan indeks kepuasan masyarakat yang merupakan laporan 2 tahun terakhir, selain menganalisis buku laporan tersebut, dilakukan analisis terhadap artikel-artikel atau website yang terdapat pada web resminya Dinas Kependudukan dan Pencatatan Sipil karena data-data umum yang lengkap sudah semua tersedia di web tersebut.

\section{HASIL DAN PEMBAHASAN}

Hasil dari penelitian ini merupakan sebuah system informasi indeks kepuasan masyarakat yang dapat membantu Dinas Kependudukan dan Pencatatan sipil dalam menyelesaikan permasalahan permasalahan yang terjadi, yang berkaitan dengan survey indeks kepuasan masyarakat. Dan telah dibahas sebelumnya bahwa metode pengembangan perangkat lunak yang digunakan adalah model prototype, maka dari itu hasil dari penelitian ini juga akan mengikuti langkah langkah dari model tersebut.

Adapun penjelasan dari masing masing langkah yaitu sebagai berikut

\subsection{Mendengarkan Pelanggan}

a. Prosedur Sistem Berjalan

Persiapan Kuisioner merupakan formulir survei yang disiapkan oleh Kepala Seksi Pengolahan dan Penyajian Data Kependudukanserta menetapkan atau menugaskan salah satu staf Pengolahan dan Penyajian Data Kependudukan sebagai pelaksana survei secara langsung ataupun dengan cara melakukan rapat secara internal. Seteleh menetapkan staf yang menjadi pelaksana survei maka Kepala Seksi Pengolahan dan Penyajian Data Kependudukan akan menyiapkan bahan survei (kuisioner) yang selanjutnya diserahkan kepada staf Pengolahan dan Penyajian Data Kependudukan yang ditugaskan sebagai pelaksana survei serta menentukan jumlah responden, lokasi dan waktu pelaksanaannya.

Setelah persiapan kuisioner selesai maka akan dilanjutkan dengan tahap penyebaran kuisionerdilakukan oleh staf Pengolahan dan Penyajian Data Kependudukan yang telah ditugaskan sebelumnya untuk menyebarkan kuisioner kepada penduduk (responden) dengan cara memberikan langsung kepada penduduk yang sedang mengantri di loket atau dilakukan pada saat sosialisasi tergantung pada lokasi yang ditetapkan.

Selanjutnya yaitu Pengisian kuisioner survei diisi oleh penduduk, dimana kuisioner tersebut memiliki sembilan unsur pelayanan yang wajib diisi secara langsung oleh penduduk (responden). Setelah kuisioner tersebut diisi oleh responden maka lembar kuisioner akan dikembalikan lagi kepada staf Pengolahan dan Penyajian Data Kependudukan yang melakukan survei. Selanjutnya Staf Pengolahan dan Penyajian Data Kependudukan menyerahkan kembali lembar kuisioner yang telah diisi kepada Kepala Seksi Pengolahan dan Penyajian Data Kependudukan.

Setelah itu, Pengolahan data hasil survei diolah oleh Kepala Seksi Pengolahan dan Penyajian Data Kependudukan secara kuantitatif yaitu dilakukan dengan cara menghitung menggunakan nilai rata-rata tertimbang, masing-masing unsur pelayanan. Perhitungan Indeks Kepuasan Masyarakat tersebut dihitung terhadap semua poin unsur pelayanan yang telah diisi oleh responden (penduduk).

Selanjutnya Penyusunan Laporan IKM dilakukan oleh Kepala Seksi Pengolahan dan Penyajian Data Kependudukan yang berbentuk sebuah buku dan nantinya akan dilaporkan langsung Kepada Kepala Dinas untuk diminta persetujuan terhadap laporan tersebut. Selanjutnya laporan yang sudah disetujui oleh Kepala Dinas akan diarsipkan untuk dijadikan bahan bukti telah dilaksanakannya survei. 
b. Diagram Activity Prosedur Sistem Berjalan

Berdasarkan dari prosedur sistem berjalan berikutnya dibuatlah diagram activity prosedur sistem berjalan agar dapat memudahkan dalam menemukan permasalahan.

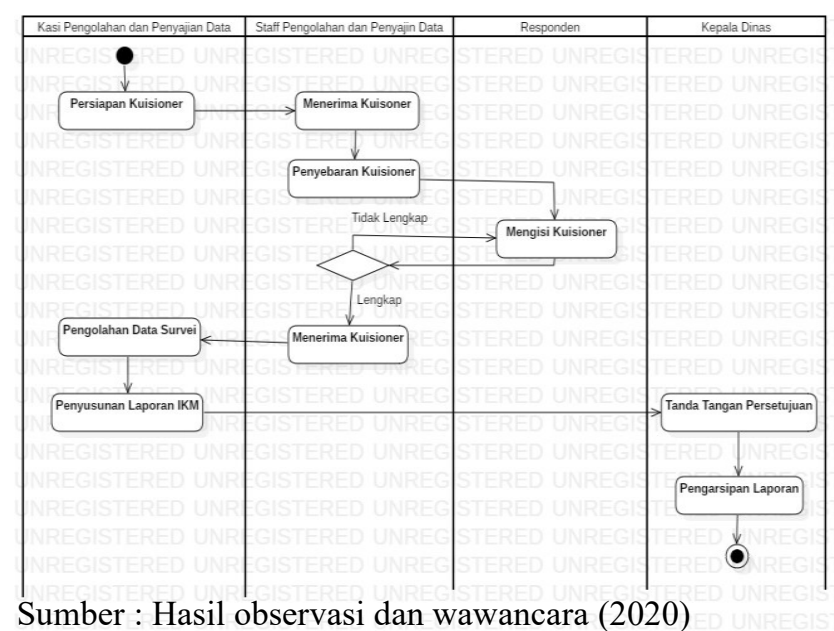

Gambar 2. Activity Diagram Sistem berjalan

\section{c. Permasalahan Pokok}

Berdasarkan pengamatan atau hasil riset maka penulis mengambil kesimpulan bahwa Kantor Dinas Kependudukan dan Pencatatan Sipil dalam proses pengelolaan Survei Indeks Kepuasan Masyarakat (IKM) mulai dari Prosedur Persiapan, Penyerahan Kuisioner, Pengolahan data hasil Survei hingga sampai pada Penyususunan Laporan data hasil survei memang belum terkomputerisasi atau masih menggunakan cara yang lama. Adapun beberapa permasalahan pokokyang ditemukan yaitu meliputi:

- Rentan terjadinya kehilangan atau kerusakan data hasil survey karena mengingat media yang digunakan untuk survei masih menggunakan kertas.

- Banyaknya waktu yang dibutuhkan dalam menyusun atau merekap poin yang berupa hasil jawaban responden (Masyarakat) padalaporan Indeks Kepuasan Masyarakat karena harus di input dan dihitung satu persatu pada setiap lembarnya.

- Pelaksanaan Survei Kepuasan Masyarakat di lingkungan Dinas Kependudukan dan Pencatatan Sipil Kabupaten masih rendah dan belum optimal, dalam arti jikalau menggunakan cara yang belum terkomputerisasi untuk proses survei bisa saja yang mengisi kuisoner tersebut adalah oknum yang merupakan salah satu pihak dari penyelenggara survei. hal ini dilakukan demi untuk memanipulasi data hasil survei sehingga nantinya akan mempengaruhi hasil perhitungan dari peniliaian Indeks Kepuasan Masyarakat atau penilaiannya bukan hasil mutlak dari masyarakat (responden).

- Kurang maksimalnya pemahaman dan timbal balik dari masyarakat merupakan salah satu penyebab terjadinya ketidakefektifan dalam pelaksanaan survei yang dilakukan karena mengingat pemahaman dan timbal balik masyarakat merupakan faktor penentu yang akan sangat berpengaruh terhadap hasil survei.
- Kualitas penyelenggaraan survei kepuasan masyarakat yang belum memenuhi kriteria sesuai dengan Peraturan Menteri Pendayagunaan Aparatur Negara dan Reformasi Birokrasi Nomor 14 Tahun 2017.

\section{d. Pemecahan Masalah}

Dengan melihat berbagai permasalahan yang ada pada sistem berjalan, maka untuk mengatasi permasalahan tersebut penulis mengajukanpemecahan masalah yang sudah terkomputerisasisehingga dapat meningkatkan efektifitas dan efesiensi dalam pengolahan data hasil Survei Indeks Kepuasan Masyarakat dimulai dari proses Persiapan Survei, Penyebaran Kuisioner, Pengolahan data hasil Survei hingga sampai pada penyususunan laporan data hasil surveiIndeks Kepuasan Masyarakat menggunakan program aplikasi berbasis website.Adapun keuntungan yang dapat diperoleh dari penggunaan aplikasi program aplikasi tersebut adalah sebagai berikut:

- Untuk mengatasi rentan terjadinya kerusakan atau kehilangan data, maka dengan adanya aplikasi yang dirancang berbasis website ini tentunya akan lebih efektif untuk menyimpan data hasil survei karena mengingat semua data survei yang telah diisi oleh responden akan otomatis tersimpan pada database.

- Memudahkan proses penyusunan data hasil survei dan perekapan poin per unsurpada setiap lembar kuisioner akan lebih cepat dan akurat karena semua data survei tersimpan pada sebuah database dapat langsung di cetak dalam bentuk laporan dalam bentuk excel atau pdf.

- Untuk mengantisipasi adanya manipulasi data dalam pengisian kuisioner survei maka proses pelaksanaan survei dilengkapi dengan fitur captchayang berfungsi untuk mengantisipasi spam yang tidak diinginkan serta dengan adanya aplikasi yang berbasis website tentunya akan lebih efektif dan efisien untuk mewujudkan kegiatan survei yang lebih transparan.

- Untuk meningkatkan pemahaman masyarakat terhadap aspek atau unsur-unsur yang terkandung pada kuisioner dengan adanya menu panduan pengisian kuisioner yang disediakan khusus untuk panduan dasar pengisian kuisioner.

- Meningkatkan kualitas dan efektifitas penyelenggaraan survei yang lebih transparan dengan cara memanfaatkan teknologi yang ada pada masa kini dianggap sebagai langkah paling tepat sesuai dengan PERMEN PAN dan RB Nomor 14 Tahun 2017. Dengan adanya aplikasi yang dirancang berbasis website tentunya akan sangat memudahkan pelaksanaan survei, penyusunan atau perekapan poin per unsur dan penyusunan laporan sehingga dapat berjalan seiring dengan perkembangan teknologi yang begitu pesat khususnya di bidang teknologi informasi.

e. Analisa Kebutuhan perangkat Lunak

Analisis kebutuhan merupakan analisa yang berkaitan dengan kebutuhan-kebutuhan yang diperlukan baik dari segi pengguna maupun dari segi sistem itu sendiri yang nantinya akan dijadikan sebagai dasar Perancangan Sistem Informasi Indeks Kepuasan Masyarakat pada Dinas Kependudukan dan Pencatatan Sipil. Yang menjelaskan 
tentang kebutuhan pengguna dan kebutuhan sistem., dan kebutuhan nya adalah sebagai berikut :

Sistem Informasi Indeks Kepuasan Masyarakat yaitu terdapat 3 user yang saling berhubungan pada satu sistem yaitu meliputi bagian Pengolahan Data yang nantinya akan disebut sebagai Admin, bagian Masyarakat atau Responden dan bagian Kepala Dinas.

Ketiga level user tersebut memiliki kebutuhan informasi yang berbeda-beda dan memiliki interaksi dengan sistem yang berbeda pula. Adapun beberapa kebutuhan informasi dan interaksi yang dimaksud adalah sebagai berikut:

1. Skenario Kebutuhan Bagian Kasi Pengolahan dan Penyajian Data

- Login: Sebelum masuk pada tampilan utama atau beranda Kasi Pengolahan dan Penyajian data harus melakukan login terlebih dahulu.

- Mengolah Kuisioner Survei: Pengolahan Kuisioner yaitu berupa menambah unsur, mengubah dan menghapus unsur.

- Mengolah Data Hasil Survei: Pengolahan data hasil survei yaitu berupa perhitungan nilai ratarata dari unsur pelayanan dengan menjumlahkan nilai masing-masing unsur lalu dibagi dengan jumlah responden yang mengisi kuisioner. Selanjutnya untuk menghitung nilai rata-rata tertimbang maka jumlah rata-rata per unsur pelayanan dikalikan dengan 0,11. Untuk mengetahui nilai persepsi per unsur dan lebih mudah dipahami maka perhatikan tabel berikut :

\section{Tabel 1}

Pengolahan Data Hasil Survei

\begin{tabular}{|c|c|c|c|c|}
\hline $\begin{array}{c}\text { Nilai } \\
\text { Persepsi }\end{array}$ & $\begin{array}{c}\text { Nilai } \\
\text { Interval }\end{array}$ & $\begin{array}{c}\text { Nilai } \\
\text { Interval } \\
\text { Konversi }\end{array}$ & $\begin{array}{c}\text { Mutu } \\
\text { Pelayanan }\end{array}$ & $\begin{array}{c}\text { Kinerja } \\
\text { Unit } \\
\text { Pelayanan }\end{array}$ \\
\hline 1 & $1,00-2,59$ & $25,00-64,99$ & D & Tidak Baik \\
\hline 2 & $2,60-3,06$ & $65,00-76,60$ & C & Kurang Baik \\
\hline 3 & $3,06-3,53$ & $76,61-88,30$ & B & Baik \\
\hline 4 & $3,53-4,00$ & $88,31-100,00$ & A & Sangat Baik \\
\hline
\end{tabular}

- Mengolah Grafik Indeks Kepuasan Masyarakat: Grafik dihasilkan dari nilai rata-rata unsur pelayanan per kuisioner yang selanjutnya akan dijumlahkan berdasarkan kinerja unit pelayanannya.

- Mengolah Laporan Indeks Kepuasan Masyarakat Pengolahan laporan IKM dilakukan dengan menghitung indeks setiap unsur pelayanan yaitu berupa perhitungan jumlah rata-rata dari setiap unsur pelayanan untuk mengetahui nilai dari setiap unit pelayanannya. Sedangkan untuk menghitung nilai gabungan pada setiap unit pelayanan yaitu dilakukan dengan menjumlahkan nilai rata-rata dari setiap unsur pelayanan lalu dikalikan dengan penimbang yang sama yakni 0,11 . Untuk mengetahui nilai unsur pada masingmasing unit pelayanan maka perhatikan tabel berikut.
Tabel 2. Pengolahan Laporan IKM

\begin{tabular}{|c|l|c|}
\hline No & Unsur IKM & $\begin{array}{c}\text { Nilai } \\
\text { IKM }\end{array}$ \\
\hline 1 & Persyaratan & A \\
\hline 2 & Sistem, Mekanisme dan Prosedur & B \\
\hline 3 & Waktu Penyelesaian & C \\
\hline 4 & Biaya/Tarif & D \\
\hline 5 & Produk Spesifikasi Jenis Pelayanan & E \\
\hline 6 & Kompetensi Pelaksana & G \\
\hline 7 & Perilaku Pelaksana & H \\
\hline 8 & $\begin{array}{l}\text { Penanganan Pengaduan, Saran dan } \\
\text { Masukan }\end{array}$ & I \\
\hline 9 & Sarana dan Prasarana & \\
\hline
\end{tabular}

Rumus untuk menghitung nilai indeks unit pelayanan yaitu : $(\mathrm{A} \times 0,11)+(\mathrm{B} \times 0,11)+(\mathrm{C} \times$ $0,11)+(\mathrm{D} \times 0,11)+(\mathrm{E} \times 0,11)+(\mathrm{F} \times 0,11)+(\mathrm{G} \times$ $0,11)+(\mathrm{H} \times 0,11)+(\mathrm{I} \times 0,11)=$ Nilai indeks Unit Pelayanan.

- Mengolah Data Kategori Indeks Kepuasan Masyarakat: Kategori Indeks Kepuasan Masyarakat diperoleh dari Nilai Interval Konversi beserta dengan kategori Kinerja Unit Pelayanan.

- Logout: Setelah menggunakan aplikasi Kasi Pengolahan dan Penyajian Data melakukan logout.

2. Skenario Kebutuhan Bagian Responden

- Membaca Panduan Pengisian Kuisioner: Panduan kuisioner disediakan agar dapat memudahkan responden dalam mengisi serta memahami semua aspek dan unsur pelayanan yang terdapat pada kuisioner.

- Mengisi Kuisioner: Pengisian kuisioner harus diisi dengan lengkap mulai dari biodata responden sampai dengan penilaian tehadap unsur kinerja unit pelayanan.

3. Skenario Kebutuhan Bagian Kepala Dinas

- login: Sebelum masuk pada tampilan utama atau beranda Kepala Dinas harus login terlebih dahulu.

- Melihat Laporan Indeks Kepuasan Masyarakat: Kepala Dinas dapat mencetak atau men-download Laporan Indeks Kepuasan Masyarakat per semester yang sedang berlangsung.

- Melihat Grafik Indeks Kepuasan Masyarakat: Kepala Dinas hanya dapat melihat grafik Indeks Kepuasan Masyarakat berdasarkan data-data yang telah diolah oleh Kepala Seksi Pengolahan dan Penyajian Data.

- Melihat Kategori Indeks Kepuasan Masyarakat: Kepala Dinas juga hanya dapat melihat kategori Indeks Kepuasan Masyarakat berdasarkan kategori Kinerja Unit Pelayanan yang telah diolah oleh Kepala Seksi Pengolahan dan Penyajian Data.

- Mengarsipkan Laporan: Pengarsipan File yang berupa Laporan Indeks Kepuasan Masyarakat dapat di-upload oleh Kepala Dinas.

- Logout Setelah menggunakan aplikasi Kepala Dinas harus melakukan logout.

\subsection{Membangun Prototype}

Setelah mendapatkan kebutuhan, mengetahui permasalahan maka langkah berikutnya adalah membangun prototype dari Sistem Informasi, adapun 
beberapa tampilan sistem informasi Indeks Kepuasan masyarakat adalah sebagai berikut :

a. Rancangan Tampilan

Pada menu login Bagian Kasi Pengolahan dan Penyajian Data Kependudukan, user yang dapat mengakses menuini hanya Kasi Pengolahan dan Penyajian Data Kependudukan. Untuk login di halaman utama websiteuser harus memasukkan usernamedan passowrd dengan benar terlebih dahulu, selanjutnya tekan tombol login.

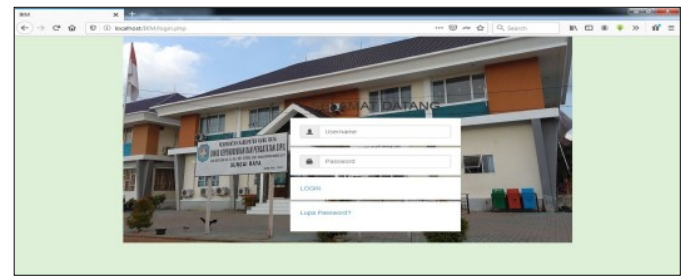

Sumber : Hasil Penelitian

Gambar 3 . Prototype tampilan login Kasi

b. Rancangan Tampilan Beranda Kasi

Pada tampilan beranda terdapat beberapa menu yang dapat diakses oleh Kasi Pengolahan dan Penyajian Data Kependudukan yaitu Data Survei, Kuisioner Survei, Grafik IKM, Laporan IKM dan Kategori IKM.

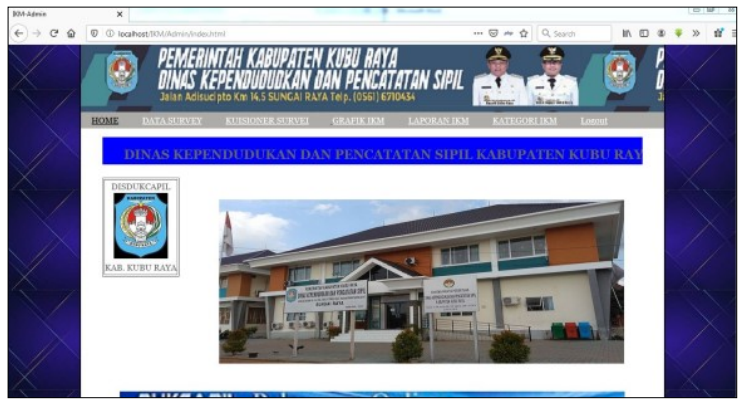

Sumber : Hasil Penelitian

Gambar 4. Prototype tampilan BerandaKasi

\section{c. Rancangan Tampilan Data Survei}

Klik pada menu Data Survei untuk melihat data survei atau data yang merupakan jawaban dari responden. Jika ingin mencetak data hasil survei maka klik tombol cetak, tekan tombol download jika ingin men-download data, tekan tombol hapus untuk menghapus data satu per satu, namun jika ingin menghapus semua data maka tekan tombol hapus semua data.

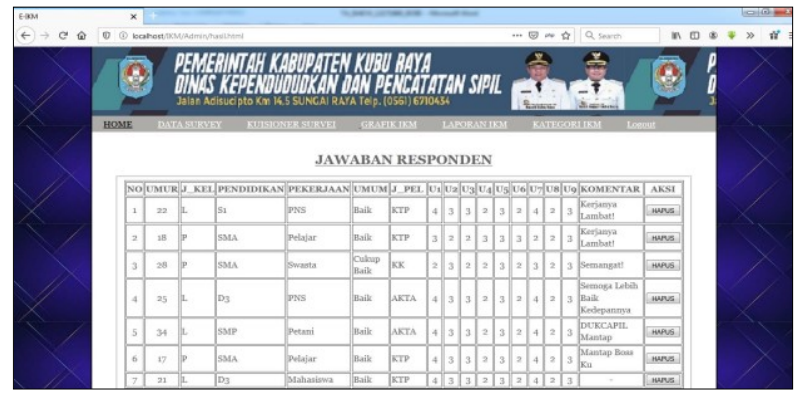

Sumber : Hasil Penelitian

Gambar 5 . Prototype tampilan Data SurveiKasi

d. Rancangan Tampilan Kuisioner Survei Kasi

Klik pada menu Kuisioner Survei untuk melihat lembaran kuisioner survei. Jika ingin menambahkan data maka tekan tombol tambah data, tekan tombol edit jika ingin mengubah data dan tekan tombol hapus jika ingin menghapus data.

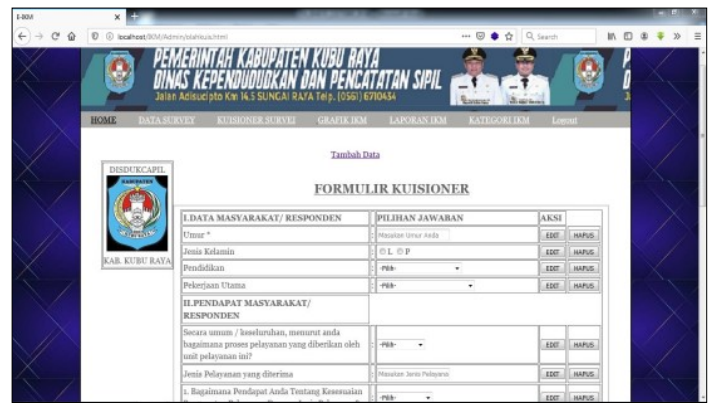

Sumber : Hasil Penelitian (2020)

Gambar 6. Prototype tampilan Kuisioner

\section{e. Rancangan Tampilan Grafik IKM}

Klik pada Menu Grafik IKM untuk melihat grafik yang merupakan hasil jawaban keseluruhan dari responden yang digambarkan dalam bentuk grafik dengan tujuan agar memudahkan dalam melihat kategori Indeks Kepuasan.

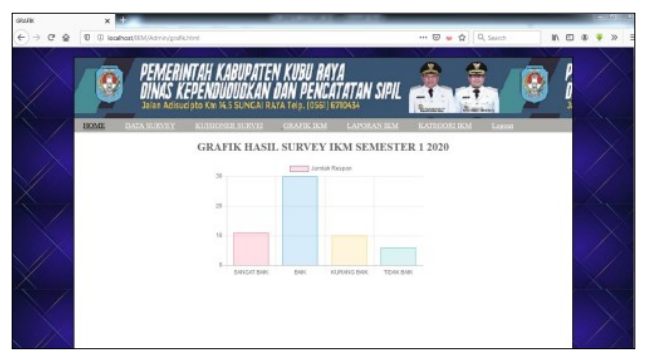

Sumber : Hasil Penelitian (2020)

Gambar 7. Prototype tampilan Grafik

f. Rancangan Tampilan Laporan IKM

Klik pada menu Laporan IKM untuk melihat kerangka penyusunan laporan IKM yang berfungsi untuk memudahkan penyusunan karena kerangka yang disediakan disini sudah lengkap hanya tinggal menambahkan data survei untuk membuat laporan IKM. Jika ingin mencetak laporan maka tekan tombol cetak tetapi jika ingin men-download laporan silahkan klik tombol download.

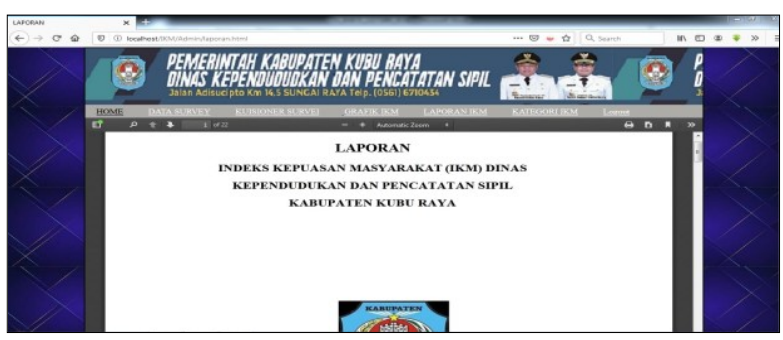

Sumber : Hasil Penelitian (2020) 


\section{Gambar 8. Prototype tampilan Laporan IKM Kasi}

g. Rancangan Tampilan Kategori IKM

Klik pada menu kategori IKM untuk melihat kategori IKM yang merupakan hasil dari perhitungan rata-rata dari semua unsur dari keseluruhan jawaban responden.

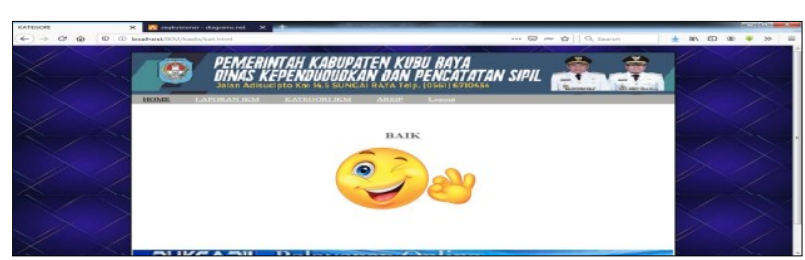

Sumber : Hasil Penelitian (2020)

Gambar 9 Prototype tampilan Kategori IKM Kasi

h. Rancangan Tampilan Logout

Klik tombol logout maka Kepala Dinas otomatis akan keluar atau kembali ke halaman login.

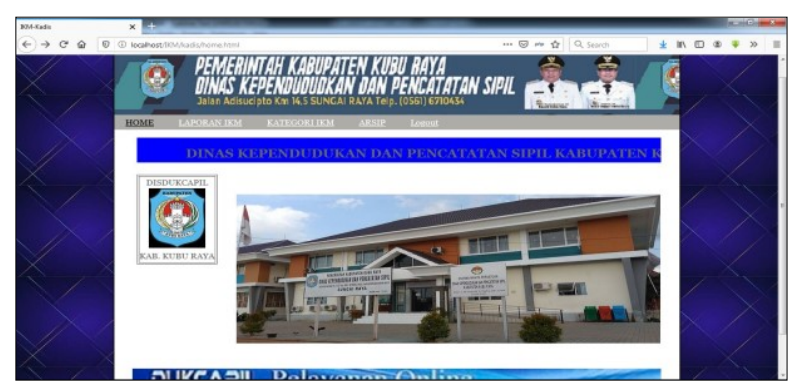

Sumber : Hasil Penelitian (2020)

Gambar 10. Prototype tampilan Logout

i. Rancangan Entitiy Relationship Diagram (ERD)

Entity Relationship Diagram (ERD)menggambarkan bentuk desain yang menghasilkan pemetaan terhadap tabel-tabel yang saling berhubungan. Dibawah ini merupakan rancangan ERD dari Sistem Informasi Indeks Kepuasan Masyarakat (IKM).

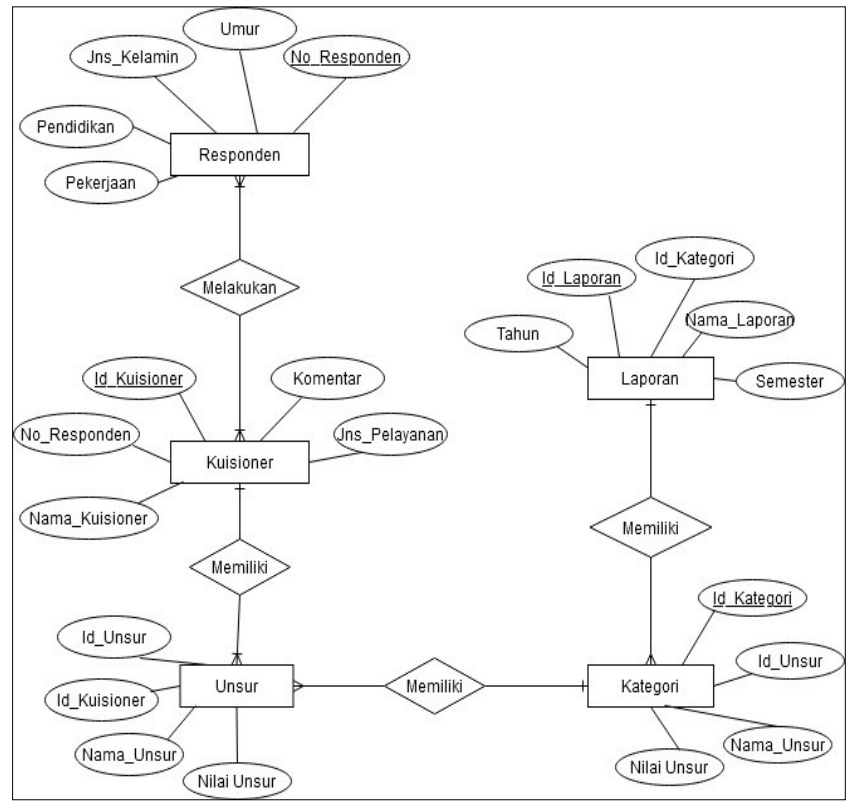

Gambar 11. Rancangan ERD j. Rancangan Logical Record Structure (LRS)

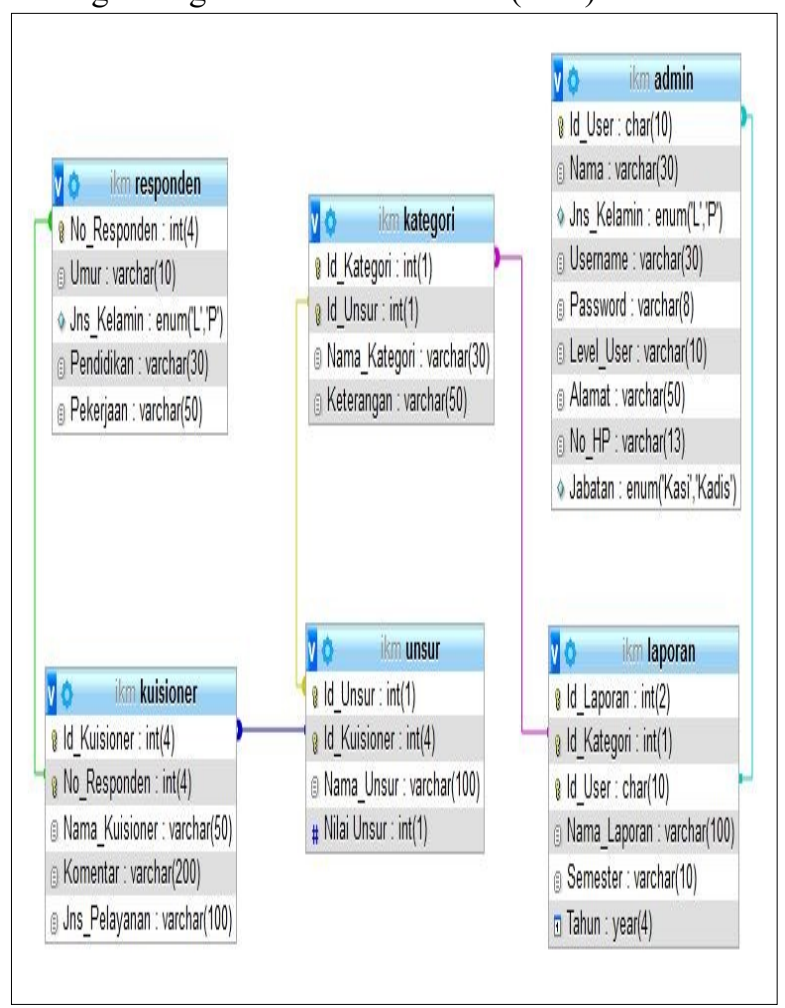

\section{Gambar 12. Rancangan Sistem Usulan LRS}

k. Diagram Use Case

Diagram use case merupakan diagram yang dibuat guna untuk memudahkan pengembangan perangkat lunak dalam memahami kebutuhan-kebutuhan fungsional sistem. Berikut ini merupakan diagram use case Sistem Informasi Indeks Kepuasan Masyarakat pada Dinas Kependudukan dan Pencatatan Sipil.

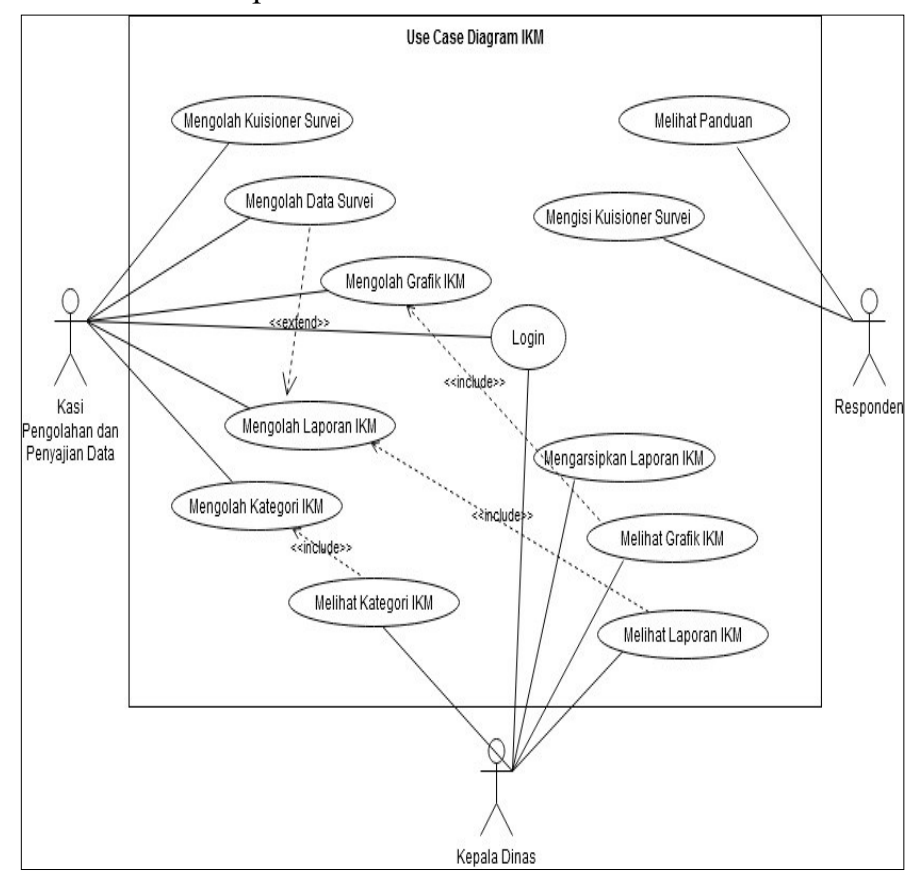

Gambar 13. Use Case Diagram SISFO IKM 
1. Diagram Aktivitas

Proses survei Indeks Kepuasan Masyarakat yang terjadi pada Dinas Kependudukan dan Pencatatan Sipil akan digambarkan menggunakan diagram aktivitas. Diagram aktivitas atau yang biasa dikenal dengan Activity Diagram digunakan untuk menggambarkan suatu langkah-langkah atau aktivitas dari sistem agar mudah dipahami. Diagram aktivitas yang dirancang pada perancangan Sistem Informasi Indeks Kepuasan Masyarakat ini terbagi dari beberapa diantaranya activity login, activity kuisioner Survei, activity pengolahan data survei dan activity pengolahan Laporan IKM.

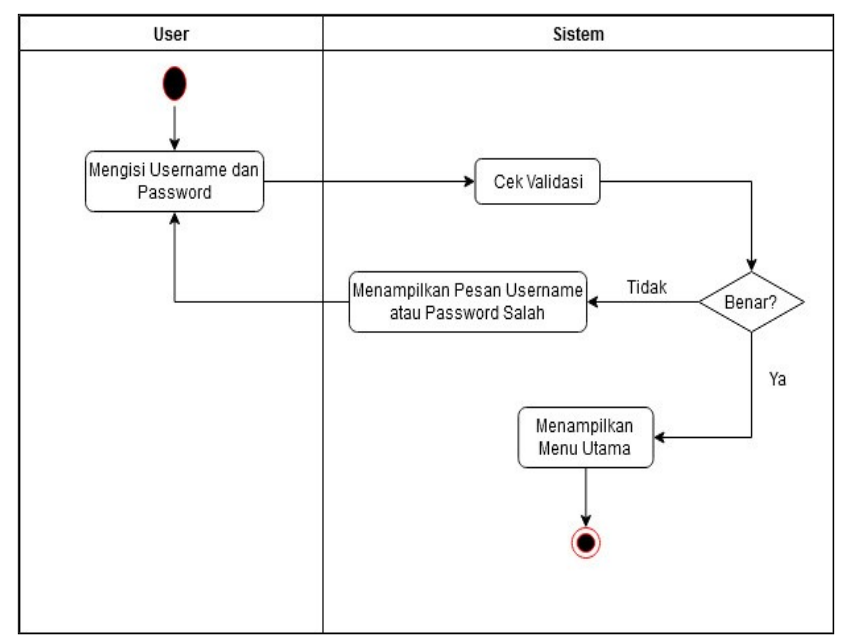

Gambar 14. Diagram Activitas Login

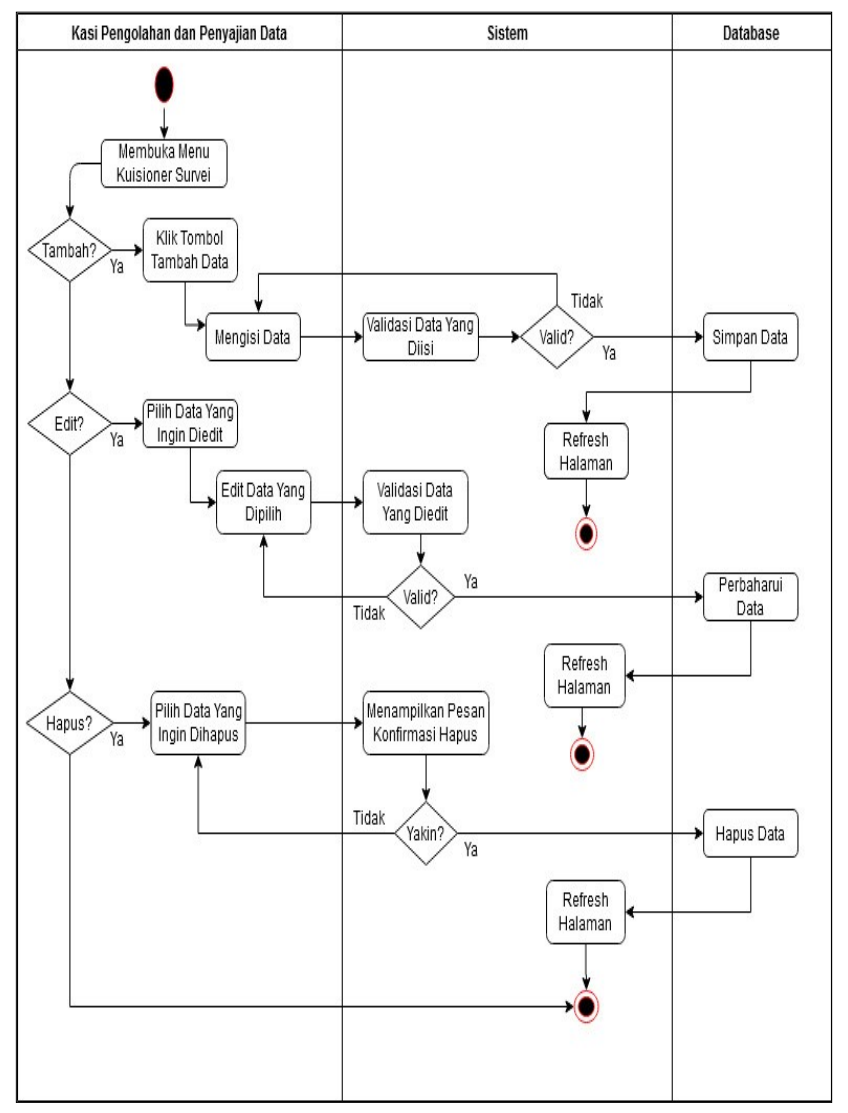

Gambar 15. Diagram Aktivitas Kuesioner Survei

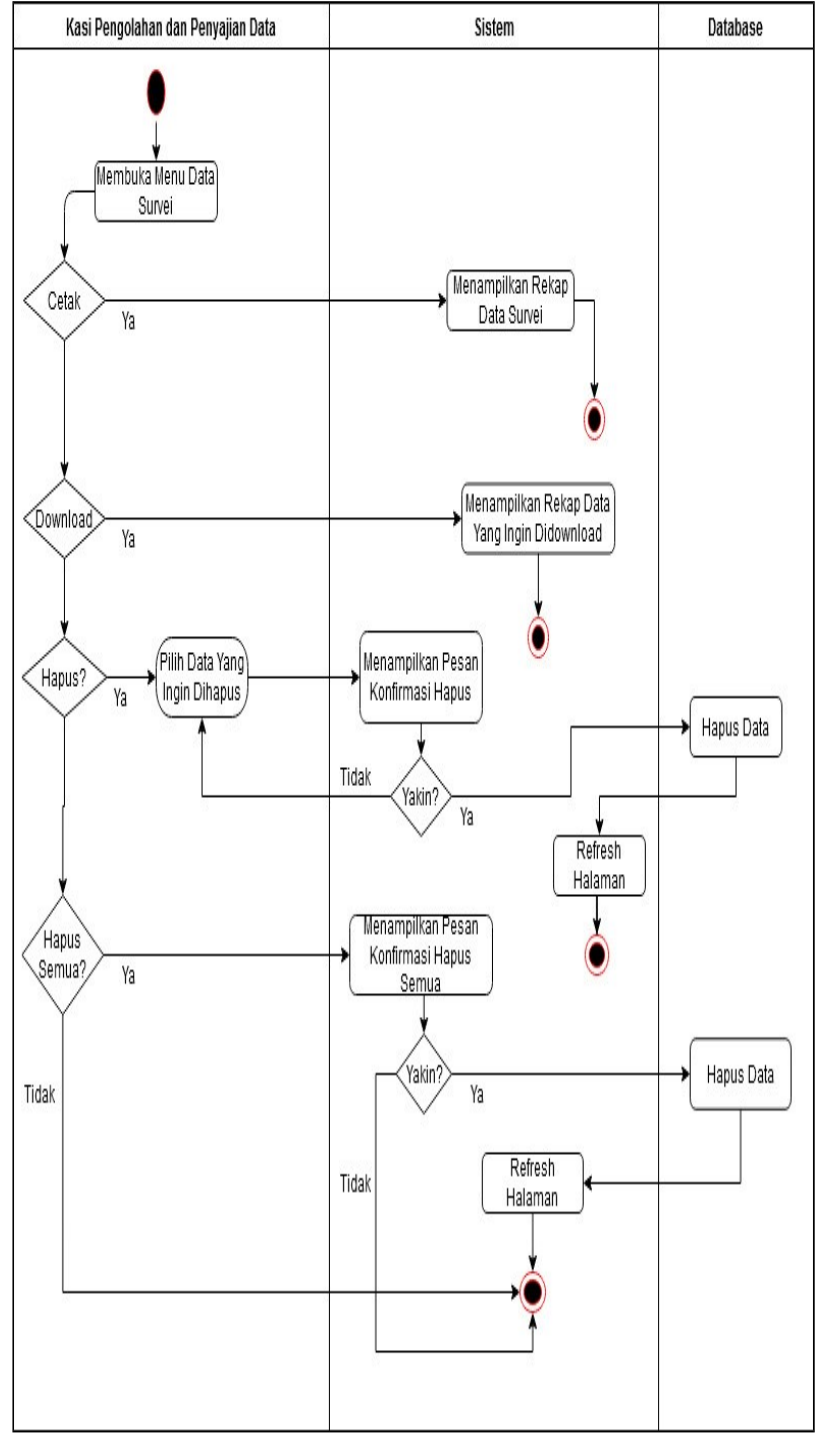

Gambar 16. Diagram Aktivitas Data Survei

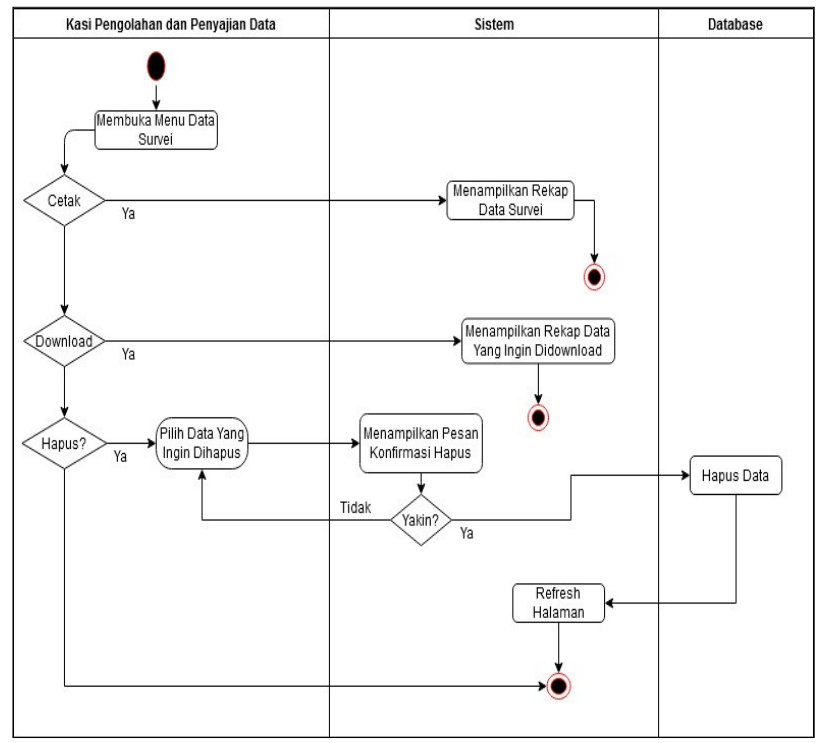

Gambar 17. Diagram Activitas Laporan IKM 


\section{KESIMPULAN}

Beberapa kesimpulan yang dapat ditarik dari Peneliaian tentang Implementasi SDLC Prototype dalam pembuatan Sistem Informasi Indeks Kepuasan Masyarakat (IKM) Pada Dinas Kependudukan dan Pencatatan Sipil Kabupaten Berbasis Website ini yaitu dapat memberikan beberapa kelebihan jika dibandingkan dengan sistem yang berjalan saat ini, yaitu sudah menggunakan sistem yang terkomputerisasi lebih baik, berikutnya karena sistem ini dibuat berbasis website maka akan lebih efektif untuk mengatasi kerusakan dan kehilangan data survey mengingat semua data otomatis tersimpan di database, dan yang terakir yaitu dengan menerapkan sistem informasi ini maka akan memudahkan pelaksanaan survey IKM dan penyusunan serta perekapan poin unsur sudah sesuai dengan ketentuan yang berlaku.

\section{DAFTAR PUSTAKA}

[1] Y. Firmansyah, R. Maulana, C. Alda Wulandari, J. Abdurrahman Saleh No, and K. Barat, "Sistem Informasi Monitoring Siswa Sebagai Media Pengawasan Orang Tua Berbasis Website," Jik, vol. 5, no. 1, 2021.

[2] R. Maulana, Y. Firmansyah, and H. Azwan, "Sistem Informasi Pelayanan Donatur Pada Komunitas 1000 Guru Kalbar Berbasis Website," I N F O R M a T I K a, vol. 11, no. 2, p. 24, 2019, doi: 10.36723/juri.v11i2.161.

[3] Hutagalung \& Arif, "Rancang Bangun Sistem Informasi Perpustakaan Berbasis Web Pada Smk Citra Negara Depok," J. Chem. Inf. Model., vol. 53 , no. 9, pp. 89-99, 2018, doi: 10.1017/CBO9781107415324.004.

[4] J. Weriza, "Sistem Informasi Berbasis Web Pada Dinas Peternakan Dan Perikanan Kabupaten Tanah Datar," vol. 3, no. 2, pp. 1-11, 2016.

[5] A. Suryadi and Y. S. Zulaikhah, "Rancang Bangun Sistem Pengelolaan Arsip Surat Berbasis Web Menggunakan Metode Waterfall," J. Khatulistiwa Inform., vol. 7, no. 1, pp. 13-21, 2019, doi: 10.31294/jki.v7i1.5738.

[6] R. Damayanti, "Sistem informasi rekam medis pasien berbasis web pada klinik nada medika pontianak," Repos. bsi, pp. 8-29, 2016.

[7] M. I. Hanafri and I. Luthfiudin, "Rancang Bangun Sistem Monitoring Kehadiran Dosen Berbasis Web Pada STMIK Bina Sarana Global," vol. 8, no. 1, 2018.

[8] R. Susanto and A. D. Andriana, "Perbandingan Model Waterfall Dan Prototyping Untuk Pengembangan Sistem Informasi," Maj. Ilm. UNIKOM, vol. 14, no. 1, pp. 41-46, 2016, doi: 10.34010/miu.v14i1.174.

[9] R. A. Sagita and H. Sugiarto, "Penerapan Metode Waterfall Pada Sistem Informasi Penjualan Furniture Berbasis Web," Indones. J. Netw. Secur., vol. 5, no. 4, pp. 1-7, 2016.

[10] D. Purnomo, "Model Prototyping Pada Pengembangan Sistem Informasi," JIMP - J. Inform.
Merdeka Pasuruan, vol. 2, no. 2, pp. 54-61, 2017.

[11] R. A. Sukamto and M. Shalahuddin, Kolaborasi Rekayasa Perangkat Lunak Terstruktur dan Berorientasi Objek. Bandung: Informatika, 2015.

[12] M. S. Maulana, "PERANCANGAN DAN PENGEMBANGAN APLIKASI WEB PENJUALAN (Studi Kasus: CV. Herson Mitra Solusindo)," J. Khatulistiwa Inform., vol. vol 2, no. no 2, pp. 175-183, 2014.

[13] Sugiyono, "Metode Penelitian Kuantitatif Kualitataif dan Kombinasi (Mixed Methods).," J. Chem. Inf. Model., vol. 53, no. 9, p. 240, 2016, doi: 10.1017/CBO9781107415324.004.

[14] Firmansyah, "Sistem Informasi Pengaduan Warga Berbasis Website ( Studi Kasus : Kelurahan Siantan Tengah , Pontianak Utara )," J. Cendikia, vol. XIX, no. April, pp. 397-404, 2020, [Online]. Available: https://jurnal.dcc.ac.id/index.php/JC/article/view/328.

[15] R. A. Siregar, R. Watrianthos, and M. Nasution, "Sistem Informasi Data Guru MDTA Pada Kantor Kesra Setdakab Labuhanbatu Berbasis Web," J. Ilm. AMIK Labuhan Batu, vol. 5, no. 2, pp. 35-45, 2017.

[16] Kemenpan, "Peraturan Menteri Pendayagunaan Aparatur Negara Dan Reformasi Birokrasi Republik Indonesia Nomor 14 Tahun 2017 Tentang Pedoman Penyusunan Survei Kepuasan Masyarakat Unit Penyelenggara Pelayanan Publik," Pedoman Penyusunan Survei Kepuasan Masy. Unit Penyelenggara Pelayanan Publik, no. 708, 2017. 